\title{
Editorial
}

\section{Economics, Business and Culture}

It has become part of a conventional wisdom, especially in the currently "integrating" Europe, to draw sharp demarcation lines between economics and culture. Cultural elitists and intellectual snobs cannot stand the thought of lowly and "vulgar" business, management or economics, while economists, politicians and businessmen have come to view culture as some sort of externality, an afterthought, "extra", indulgence, or capricious, business-like investment.

Buying, displaying and consuming products of culture does not imply living in culture or even living culturally. Living comfortably, efficiently and fully in a well-organized family unit, without the obnoxious exhibitionism of post-modern art, does not necessarily indicate cultural impoverishment. Producing a good automobile in a good and employee-friendly factory, is as much a reflection of culture as "producing" waves of bad pop music or inept and pretentious "celebrity" paintings.

There exist even entire nations, governments and states which self-characterize themselves as being "cultural" or "of culture", while producing and employing the atrapas of Attalis and paying for their vulgar marble lobbies and spilled champaign on the steps of modern "banca rotas" of monetary cathedrals. Others show proudly the exquisite achievements of their predecessors, the ancient builders, architects and engineers, while being themselves strikingly and openly incapable of securing even minimally civilized conditions and security for their own employees and citizens.

There are economic and business theories and practices that are purposefully and radically noncultural or acultural, unable to expand (or even express) human values, professional pride, sense of

IOS Press

Human Systems Management 12 (1993) 171-174 achievement, quest for quality and joy of satisfaction. There are still societies totally (and even programmatically) incapable of learning and therefore devoid of culture by definition.

Economics, organization and quality of production, service and employment, should not be separated from culture. In many ways they are culture's most reliable and most expressive manifestations.

How can degrading working conditions, shoddy production practices, governmental arrogance and disregard for its tax-subjects, inefficient and inconvenient services, unimaginative management and a disordered, dirty environment be expressions of culture or cultural society? Is not satisfying, wellorganized, high-quality and high-productivity enterprise a more important and more challenging embodiment of human culture than finger-painted, multi-color "creations" defacing medieval cathedrals and public walls? Is not affordable, useful, safe and high-quality product a better measure of nation's culture than "primitive" straw hats, "hand-painted" kitsch, street bazaars, folk "art" and other products of post-modern pseudoculture?

How cultural can a country be which cannot affordably feed its own citizens, wastes or sells its natural resources, allows crime and exploitation to go rampant, sells its own cheap labor (and bodies), confuses entrepreneurship with black-market "handel", degrades employees into biblical "hirelings", and makes most of its services, stores and shops unavailable precisely when employees, especially mothers, are returning home from the day's work?

A century or two ago, it was the builders, the producers, the artisans, engineers, inventors, architects and mathematicians, often integrated within a single person, who were widely recognized as creators and contributors to culture, along with 
musicians, painters, educators and writers. Now they themselves (and quite voluntarily) have abandoned their initial cultural embedding in the society by promoting their own "crafts" and professions as being culture- or value-free.

Management, business, organization and entrepreneurship cannot be culture-free, they are not separated from culture and thus should not be devoid of culture.

The image of a great violinist or accomplished mathematician playing polkas or selling cigarettes in the shade of some great East European cathedral comes to mind: human culture and civilization are being subjected to the externally prescribed "shock therapy", imposed from without, but damaging from within. Old and proud cultures are rapidly withering away, giving out under the monetaristic onslaught of the new barbarians of culture-free "economics". Only the ex-communists and their international financiers appear to be applauding.

What is culture?

Culture usually refers to the learned or created (heteropoietic) environment, providing the milieu for human communication, interaction and adaptation within the broader ecological surroundings.

Culture is essentially non-biological and nongenetic: it cannot be inherited. It can be preserved and enhanced only through education, training, learning and experience. Culture has its social (interpersonal relationships, rules of behavior, patterns of organization), material (arts, crafts, products) and spiritual (values, ideas, goals) dimensions, often inseparable and always complementary.

Most higher organisms seem to exist in "culture" of some sort, based on simple mimicking, aping, repeating, conditioning, observing, etc.

Culture is mostly autonomous and self-organizing, sufficiently independent of the underlying bio-genetic evolution. However, some genetic influences (basic human "substrate") undoubtedly contribute to cultural differences: cultures of humans and apes, whites and blacks and males and females will undoubtedly differ, due to obvious differences in social embedding, anatomy, physiology and so on. Similarly, business and management cultures of different nations will differ because of their differential location, history, focus and educational efforts.
Culture is dynamic, never static. It evolves, changes and continually renews itself on the basis of its own inner rules of conduct and behavior, yet it is reacting to external signals, pressures and deformations. Culture, as a network of relationships, is recursively self-renewing (autopoietic), but not once-and-for-all produced (allopoietic). Culture is and always must be the product of culture as life itself is product of life. Culture cannot be designed externally by social engineers, although Hitler, Stalin and Mao have certainly tried.

The heteropoietic products of culture (artifacts, architecture, paintings, writings, etc.) do not constitute culture in themselves, but are its fruits and manifestations. Products of culture should be distinguished and differentiated from culture as a poietic process and network of relationships.

Autopoietic culture persists in spite (and even because) of the continuous flux (birth, death) of its individual components (specific human beings): it maintains its autonomy, adaptability and inner order over time. Allopoietic culture (artificial "machine" produced by propaganda and social engineering) collapses with the demise or exit of its key individuals: it is not self-renewing. "Culture" which emerges and declines with the life cycle of a specific cohort of individuals is not culture: it has not been transferred (or is untransferable) through learning.

Human culture, the whole human society, is an autopoietic complex of its individual (also autopoietic) component cultures of nations, races, tribes, families, enterprises, groups and regions, defined and existing in specific time, space and language.

Such all-human culture evolves and manifests itself only locally. The old slogan "Think globally act locally" is not just a cliché, but an expression of wisdom, a prerequisite for successful human cultural existence.

Language provides the necessary environment for human cultural self-production and evolution. It facilitates consensual coordination of human action. Linguistic differentiation, the "Tower of Babel", is therefore a necessary reflection of historical specificity of time and space of ancient protocultures.

Products of previous cultures (architecture, art, music) are not necessarily reflections and certainly 
not products of contemporary cultures. Yet, current cultures do use, exploit, destroy or even appropriate the cultural products of the past.

Revered medieval bridges, adorned with exquisite sculptures of Saints and Heroes, now serve as flea markets of kitsch and venues for the acultural peddling of "arts", of today's "Bohemia”. Bad music, bad poetry, loud quasi-dixieland and assorted mimes, rikshas and hamburger-sellers degrade even the most beautiful of medieval squares in Prague, Budapest or Cracow. Majestic castles of kings serve as residencies to mediocre playwrights, electricians and other Kulturträgers (some even using scooters or skateboards for pedalling through historical carridors - expressing their own "culture' quite poignantly). Historical buildings are commonly defaced by graffiti, commercial messages and technicolor biliboards of tobacco multinationals.

Yet, even the most decadent of contemporary cultures do produce their own products and their own networks of cultural relationships. Often, these productions are not related to or stimulated by traditional religion, war, science or discovery. Increasingly they are related to production and consumption, organization of life and business, entrepreneurship and communication infrastructure.

A well-run, well-organized and competitively productive enterprise, providing work fulfillment and secure family lives for thousands of human beings, represents more potent and more expressive cultural achievement than a hand-made mug, selfabsorbed painting or forgettable piece of pop music.

What is "cultural" about listening to Borodin, reading Dostoyevsky or viewing the Swan Lake and then commiserating in endless queues in order to buy bread and butter or to exchange a few rubles? What is so cultural about visiting a graffitismeared gallery in apprehension of being blown up to pieces by terrorist bombs? How can living in fear and uncertainty be compatible with living in culture or living culturally - in any culture?

Culture is very selective: it continually screens and filters its candidate manifestations. Although culture produces, quite naturally and neutrally, both good and bad, art and kitsch, efficiency and sloth, it is only what is judged and perceived as good, beautiful and of quality that is allowed to enter and become part of persisting selection of culture. It falls only on the contemporaries to do the producing, but mostly on their posterities to do the selecting.

Recent efforts to destroy the great pyramids, the Cultural Revolution and the burning or banning of books are typical examples. Galleries, churches and museums are being bombed by members of cultural nations. How many priceless cultural achievements were destroyed by their contemporaties and how many mediocrities were passed on? How many originally hated or ignored products of culture have later become the most revered cultural pinnacles?

Living in culture cannot mean selling (and buying) bric-à-brac wares or changing money in the shade of a cathedral. Nation's culture cannot be measured only by its past achievements (i.e., achievements of a different culture), but mainly by its current behavior, rules of conduct and production relationships.

Firing and hiring tens of thousands of employees at will may be a good cost-cutting tool, but it is not good business or management, not good organization and certainly not good culture. Culture of "Caveat emptor" is fundamentally different and from many vantage points also decidedly less adaptable than the culture of "Our customer - our master".

In spite of its current mathematical pseudoobjectivity and rationality, despite of monetaristic "shock therapies" and political meddlings, economics should be recognized as an integral part of human culture. The art of organizing production, consumption and society at large is truly the greatest of arts, to be practiced only by the most competent and qualified artists, not just by intellectually residual elite of technocrats.

So far, we do not require any education, standards, experience or knowledge from politicians, businessmen and executives. Still, one cannot even be a veterenarian or experiment with guinea pigs without acquiring minimal education and demonstrating required skills and capabilities. Yet, we do allow and often condone social experimenting with millions of human beings on a large scale, conducted by individuals with superficial knowledge, 
minimal or limited experience and inadequate or obsolete education.

Where self-proclaimed people of culture would rise in just anger against the "heartless" experimentation with monkeys, rats and chicken, the same people of culture often condone and even applaud the hazardous and reckless (often criminal) social experimentation with human beings and their families. Large-scale experiments with human beings are even today being supported and generously financed all across Russia and Eastern Europe. The devastation of these old European cultures, temporarily weakened socially, economically and religiously, is accepted, being taken for granted and often advised and financed by other people of culture.
One negligently lost patient constitutes for a doctor a problem to be explained, investigated and often severely penalized. Still, millions of people are lost, displaced or degraded by the negligence of a politician and his social experiments or "shock therapies" - and nothing happens: all is forgiven, forgotten or passed over in silence. That, the inappropriate and cowardly silence over the suffering of others, must in itself be a result of culture.

Milan ZELENY

Graduate School of Business Fordham University at Lincoln Center New York, NY 10023

U.S.A. 